\title{
Diet changes in fish species from a large reservoir in South America and their impact on the trophic structure of fish assemblages (Petit- Saut Dam, French Guiana)**
}

\author{
B. de Mérona ${ }^{1 *}$, R. Vigouroux ${ }^{2}$ \\ ${ }^{1}$ IRD - LEHF, Université Cl. Bernard Lyon 1, 69622 - Villeurbanne cedex, France \\ ${ }^{2}$ HYDRECO - Laboratoire de Petit-Saut, B.P. 823 - 97388 - Cayenne cedex, France
}

\begin{abstract}
The prediction of the composition and structure of fish communities in reservoirs is essential in the management of the fisheries, an activity fundamental in emerging countries where human riverine populations depend on freshwater fish for their animal protein supply. The transformation of the river in a reservoir constitutes an environmental filter for the riverine fish species which, before anything else, must find food resources in the reservoir for their individual maintenance. After the closure of PetitSaut Dam in 1994, fish were sampled by gillnets in the Sinnamary River in the period 1994-2000 and in the Petit-Saut Reservoir between 1998 and 2000. The stomach contents of the main species were analysed for 6 main food items. Analyses of similarity were conducted in order to compare river and reservoir diets of individual species on one hand and the trophic structure of fish assemblages on the other. Twelve species out of 23 analysed showed significant modifications in their feeding habits. The changes affected species from every feeding guild as established from the river stomach contents data. As a consequence the trophic structure was deeply modified in the reservoir. The abundance of piscivores and herbivores decreased while the relative importance of omnivores and invertivores increased. There was a general tendency for species to increase their food niche breath. The ability of species to modify their feeding habits is shown to be of fundamental importance for the trophic organization of the fish community in the Petit-Saut Reservoir.
\end{abstract}

Keywords : tropical fish community, stomach contents, diet plasticity, dam impact, trophic structure.

\section{Introduction}

In emerging countries freshwater fish constitute an important supply of animal proteins for riverine populations (Shrimpton \& Giubliano 1979). As a consequence inland waters fisheries are generally well developed (Welcomme 1979). Dams' construction and the subsequent formation of large reservoirs disrupt the organization of the fisheries (Mérona 1990, Santos \&

* Corresponding author :

E-mail: bernard.de-merona@univ-lyon1.fr

** A study presented at the $47^{\text {th }}$ congress of the French Limnological Association (AFL), 2004, Besançon, France. Guest Editor : Odile Fossati.
Mérona 1996). Exploitation of the reservoir involves different methods of capture related to the change in fish communities' structure. In these situations, in order to avoid a shortage in markets' supply, some kind of anticipation of the structure and composition of fish communities in the reservoir is essential for its management. The formation of a reservoir, or the transformation of a river into a lake, forms an environmental filter through which only the species exhibiting strategies adapted to the new environment will pass (Tonn et al. 1990, Poff 1997). The first species to be excluded are species morphologically and physiologically adapted to strong currents and oxygen saturation (Welcomme \& Mérona 1988). Pool species will be first selected based on their feeding strategies being that feeding exercises a primary influence on further activity, growth, reproduction and correlated aspects of fitness (Hugues 1993). 
Published data on the trophic structure of fish communities in reservoirs show a great variability of the results. The only general tendency is a reduction in the proportion of detritivores. Piscivores, invertivores or omnivores can become dominant depending on the studied situation (Agostinho et al. 1999, Mérona et al. 2001, 2003, Densen \& Morris 1999, Kubečka 1993). Observed trophic structures depend on various factors : 1) the period of the observations in relation with the succession in the reservoir formation $(\mathrm{Ku}-$ bečka 1993, Agostinho et al. 1994, Hahn et al. 1998, Mérona et al. 2003), 2) the main characteristics of the reservoir such as its position in the basin, mean depth, extension of the littoral zone, drawdown (Bernacksek 1984), and 3) above all, the composition of the fish fauna in the dammed river (Agostinho et al. 1999). Although this last factor has been pointed out by these authors as the main determinant of the composition of fish fauna in reservoirs, it has never been systematically investigated. There are two aspects related to this factor. In order to pass through the environmental filter fishes must either find in the new environment the food they are adapted to, or they must be able to change their diet according to the nature of the food present. In a previous work we have shown that species pertaining to the omnivore feeding guild in the river were dominant in the first stage of Petit-Saut reservoir formation (Mérona et al. 2003). However this dominance diminished afterward suggesting later recovery by fishes from other more specialized guilds. In this work we investigate the way these species adapt to the new resources.

We had three main objectives: 1) identify the main species which change their feeding habits, 2) integrate these changes in the construction of the trophic structure and demonstrate the changes in that structure from the pool habitats in the river to the reservoir, and 3) estimate the relative impact of these changes on the establishment of the trophic organisation of the reservoir fish community.

\section{Material and Methods}

\section{Site description}

Detailed description of the study site can be found in Mérona et al. (2003). In short, Petit-Saut Dam is located in French Guiana on the Sinnamary River (Fig. 1), a medium sized river with a drainage area of $6565 \mathrm{~km}^{2}$ and a mean annual discharge of $230 \mathrm{~m}^{3} \mathrm{~s}^{-1}$ (Tito de Morais \& Lauzanne 1994). The climate in the region is tropical humid with a mean annual precipitation of about $3000 \mathrm{~mm}$. The mean water temperature in the river before the damming varied between 25 and $26{ }^{\circ} \mathrm{C}$ (Richard et al. 1997). The dam, planned for electricity production, was constructed at about $60 \mathrm{~km}$ from the estuary and closed in January 1994. It led to the inundation of more than $350 \mathrm{~km}^{2}$ of pristine tropical forest. The surface water temperature in the reservoir can reach $32{ }^{\circ} \mathrm{C}$ in the dry season but most of the time it varied between 28 and $30{ }^{\circ} \mathrm{C}$ (Richard et al. 1997). Thermal stratification was rapidly established but was less marked at the beginning of the rains (January- February - Richard et al. 1997). In the first 2 years after the closure, large supplies of plant material and terrestrial invertebrates were observed falling in the aquatic compartment. This quantity of exogenous biomass progressively diminished during the subsequent years.

\section{Fish sampling}

Fish sampling has been described in a previous study (Mérona et al. 2003). We used two sets of 10 surface gillnets $25 \mathrm{~m}$ long by $2 \mathrm{~m}$ height of different mesh sizes. The nets were set at about 05:00 p.m. and removed between 07:00 and 10:00 a.m. the next day. In the river, the nets were positioned along the banks in areas of low water current (pools) whereas in the reservoir the former canal of the river and the marginal areas were sampled. Two zones of the reservoir were sampled: one in the lower part, at about $5 \mathrm{~km}$ from the dam, and the other in the middle part at about $50 \mathrm{~km}$ from the dam. In the river, sampling took place in an area immediately above the upper limit of the reservoir until December 1996 and after that in three stations located at increasing distances upstream from the lake (Fig. 1). In the reservoir sampling was done twice a year from June 1998 to November 2000 whereas in the river sampling covers the period 1994 to 2000, on a nearly monthly basis from 1994 to 1996 and twice a year from 1997 on. Based on the results of a previous work showing no difference in trophic structure in the three stations upstream from the reservoir (Mérona et al. 2003) we pooled these samples for the analysis. There are a total of 35 samples in the river and 12 in the reservoir. Gillnet sampling to study fish communities has some shortcomings because of the highly selective nature of this fishing method (Hamley 1975). First of all it is unsuitable to sample fast running water habitats. However, in this work we were interested in species able a priori to adapt to a lacustrine habitat which are those inhabiting the pools in the river. Furthermore the use of a large range of meshes, the multiplicity of samples, and the care taken through the investigation to sample every habitat in a zone can reduce the bias associated with gillnet sampling (TejerinaGarro \& Mérona 2000) and were adopted in this study. 


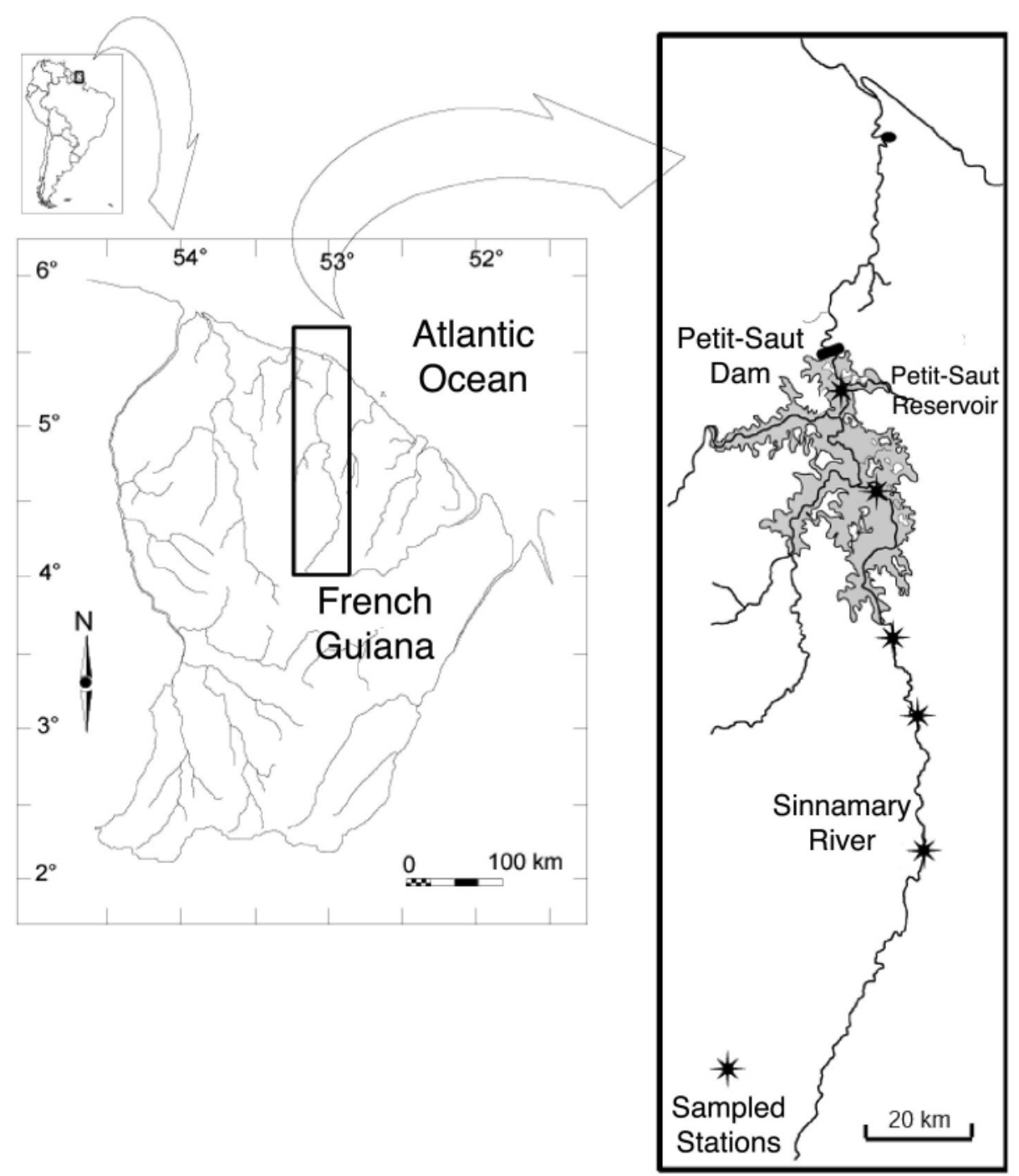

Fig. 1. Location of study site with indication of sampling stations.

In wide tropical rivers, where other sampling methods are difficult or impossible to utilize, gillnet sampling has been shown to be efficient in detecting changes in fish community structure (Tejerina-Garro et al. 1998, Mérona et al. 2001).

\section{Stomach content analysis}

In the field, after identification of the species (Planquette et al. 1996, Keith et al. 2000, Le Bail et al. 2000) individual fishes were measured and weighed and a maximum of 10 specimens of adult size of each species were taken at random, their stomachs removed from the visceral cavity and preserved in $70 \%$ alcohol. In the laboratory, the contents (if any) were spread in a Petri dish and the different items separated under a stereomicroscope. All analyses were supervised by the first author. Scores were attributed to each item based on their volumetric percentage in the stomach estimated visually (Point method - Wootton 1999). Items recognized in the stomachs were organic layer (periphyton, sediment and detritus), superior plants (leaves, fruits and seeds and plant remains), plankton, fish, decapod, terrestrial invertebrates and aquatic invertebrates. 
Data treatments

Feeding guilds were determined from the matrix of stomach contents by an adapted stepwise procedure (Mérona et al. 2001), that is:

- Step 1: more than $70 \%$ of organic layer, detritus or sediment in the stomachs: detritivores.

- Step 2: more than $70 \%$ of plankton in the stomachs: planktivores.

- Step 3: more than $70 \%$ of fish and decapods in the stomachs: piscivores.

- Step 4: more than $70 \%$ of invertebrates in the stomachs: invertivores.

- Step 5: more than $70 \%$ of plant material in the stomachs: herbivores.

- Step 6: none of the above statements: omnivores.

The overall trophic structures of the two fish species assemblages were then defined by the proportion in biomass of each feeding guild identified. Global differences between trophic structures as well as between individual species' diets in the two habitats were tested by non-parametric analyses of similarity (Anosim Clarke 1993). This analysis compares groups of samples from a distance matrix transformed to ranks. It gives a global index called global $\mathrm{R}$, which is tested by permutations of the objects. The method also allows pair wise comparisons of the samples. Feeding niche breadths were computed as the inverse sum of squared proportions of each food item in the stomachs. Overlaps between each pair of species' diets in the assemblages were computed using the formula of Morisita (1959). Generally, values equal or greater than 0.60 are assumed to represent high dietary overlap (Zaret \& Rand 1971). Difference in overlaps distribution between sites was tested by a chi square test.

\section{Results}

We were able to examine the stomach contents of 42 of the 72 species in the river, representing more than $99.4 \%$ of the total biomass captured, and 27 of the 42 species in the reservoir representing $98.9 \%$ of the total biomass captured.

Twenty three species, common to the two habitats and with enough stomach contents data to conduct valid similitude analyses, were used to compare individual diets between the river and the reservoir (Table 1). These species, which include members of the different feeding guilds as established from diet analyses in the river, represented $86.4 \%$ and $98.6 \%$ of the total capture in the river and the reservoir respectively.
The general tendencies were a large decrease in the relative contribution of terrestrial plant material and a parallel increase in aquatic invertebrates. Twelve, out of 23, showed a significant difference between the river and the reservoir. Among the piscivores, one small sized species (Charax pauciradiatus) substituted fish for aquatic invertebrates whereas the two other remained exclusive fish predators. Most invertivores consumed aquatic invertebrates instead of terrestrial invertebrates. This tendency to feed upon aquatic invertebrates was also observed for omnivores like Moenkhausia georgiae, Poptella brevispina and Triportheus rotundatus which thus substituted part of their food of terrestrial origin. The stomachs contents of benthic feeders like Hemiodus unimaculatus, Hemiodopsis quadrimaculatus and Hypostomus gymnorhynchus which were mainly composed of algae and detritus in the river were found to contain large quantities of aquatic invertebrates or plankton. Three herbivores (Leporinus friderici, L. granti and Myleus rhomboidalis) changed their diet to preying upon fish and aquatic invertebrates while two (L. fasciatus and M. ternetzi) maintained a diet based on terrestrial plants.

The trophic structure of the reservoir was significantly different from that of the river (Global $\mathrm{R}=$ $0.271 ; p=0.002$ - Fig. 2). The difference is mainly due to a large reduction in abundance of the piscivore and herbivore guilds and an increase in the omnivore guild (Table 2).

The comparison of the distributions of overlaps between species diets also showed a significant difference (chi square $=306.22 ; \mathrm{p}<0.001-$ Fig. 3 ). The relative contributions of highest and lowest values of overlaps were reduced.

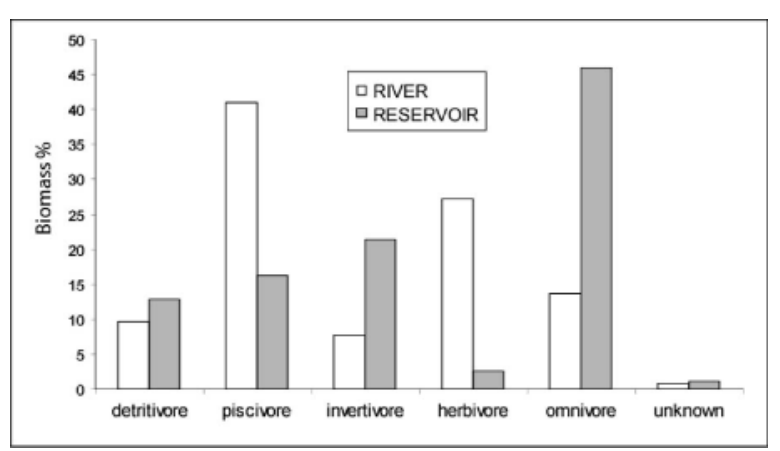

Fig. 2. Comparison of the relative contributions of feeding guilds in the trophic structures of fish communities in the Sinnamary River (1994-2000) and the Petit-Saut Reservoir (1998-2000). 
Table 1. Results of stomach content analysis on the main fish species in the Sinnamary River and the Petit-Saut Reservoir, corresponding niche breath and probabilities associated with the analysis of similarity between site.

\begin{tabular}{|c|c|c|c|c|c|c|c|c|c|c|}
\hline $\begin{array}{l}\text { Species authority } \\
\text { Feeding guild in the river/in the reservoir }\end{array}$ & 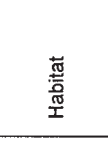 & $\frac{\infty}{z}$ & 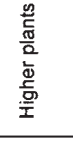 & 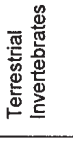 & 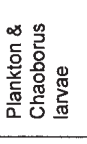 & 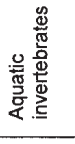 & 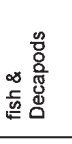 & 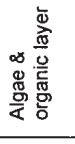 & 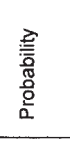 & 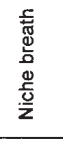 \\
\hline Astyanax bimaculatus (Linné, 1758) & River & 5 & 30 & 70 & 0 & 0 & 0 & 0 & \multirow{2}{*}{0.048} & 1.724 \\
\hline Invertivore/piscivore & Reservoir & 5 & 8 & 20 & 0 & 4 & 68 & 0 & & 1.959 \\
\hline Acestrorhynchus guyanensis Menezes, 1969 & River & 22 & 0 & 0 & 0 & 0 & 100 & 0 & \multirow{2}{*}{1.000} & 1.000 \\
\hline Piscivore/piscivore & Reservoir & 27 & 0 & 0 & 0 & 0 & 100 & 0 & & 1.000 \\
\hline Auchenipterus nuchalis (Spix, 1829) & River & 147 & 10.54 & 81.61 & 3.17 & 4.12 & 0.54 & 0 & \multirow{2}{*}{0.001} & 1.471 \\
\hline Invertivore/invertivore & Reservoir & 30 & 5 & 19.67 & 0 & 72.33 & 0 & 3 & & 1.769 \\
\hline Bryconops affinis (Günther, 1864) & River & 60 & 5.17 & 90.61 & 0 & 4.22 & 0 & 0 & \multirow{2}{*}{0.001} & 1.211 \\
\hline Invertivore/invertivore & Reservoir & 17 & 0 & 65.29 & 0 & 26.47 & 0 & 8.24 & & 1.987 \\
\hline Bryconops caudomaculatus (Günther, 1869) & River & 118 & 21.8 & 76.26 & 0 & 0.75 & 0.85 & 0.34 & \multirow{2}{*}{0.725} & 1.589 \\
\hline Invertivore/invertivore & Reservoir & 58 & 4.31 & 85 & 1.72 & 7.24 & 0 & 1.72 & & 1.369 \\
\hline Curimata cyprinoides (Linné, 1758) & River & 16 & 0 & 0 & 0 & 0 & 0 & 100 & \multirow{2}{*}{0.288} & 1.000 \\
\hline Detritivore/detritivore & Reservoir & 7 & 5.71 & 8.57 & 0 & 0 & 0 & 85.71 & & 1.342 \\
\hline Charax pauciradiatus Günther, 1864 & River & 13 & 0 & 7.69 & 0 & 0 & 92.31 & 0 & \multirow{2}{*}{0.001} & 1.166 \\
\hline Piscivore/invertivore & Reservoir & 36 & 5.56 & 15.28 & 0 & 78.61 & 0 & 0.56 & & 1.552 \\
\hline Cyphocharax spp. & River & 35 & 11.90 & 0 & 0 & 2.14 & 2.38 & 72.86 & \multirow{2}{*}{0.119} & 1.831 \\
\hline Detritivore/detritivore & Reservoir & 5 & 4.44 & 6.67 & 0 & 8.89 & 0 & 80 & & 1.528 \\
\hline Doras carinatus (Linné, 1766) & River & 11 & 9.09 & 9.09 & 0 & 32.12 & 0 & 46.06 & \multirow{2}{*}{0.191} & 3.013 \\
\hline Omnivore/invertivore & Reservoir & 5 & 0 & 8 & 0 & 92 & 0 & 0 & & 1.173 \\
\hline Hoplias aimara (Valenciennes, 1840) & River & 10 & 0 & 0 & 0 & 0 & 100 & 0 & \multirow{2}{*}{1.000} & 1.000 \\
\hline Piscivore/piscivore & Reservoir & 7 & 0 & 0 & 0 & 0 & 100 & 0 & & 1.000 \\
\hline Hemiodus unimaculatus (Bloch, 1794) & River & 12 & 1.67 & 0 & 0 & 0 & 0 & 98.33 & \multirow{2}{*}{0.010} & 1.034 \\
\hline Detritivore/omnivore & Reservoir & 7 & 0 & 14.29 & 0 & 42.86 & 0 & 42.86 & & 2.579 \\
\hline Hypostomus gymnorhynchus (Norman, 1926) & River & 3 & 0 & 0 & 0 & 0 & 0 & 100 & \multirow{2}{*}{0.133} & 1.000 \\
\hline Detritivore/omnivore & Reservoir & 7 & 14.29 & 14.29 & 57.14 & 0 & 0 & 14.29 & & 2.579 \\
\hline Hemiodopsis quadrimaculatus (Pellegrin, 1908) & River & 35 & 28.57 & 0 & 0 & 1.14 & 0 & 67.43 & \multirow{2}{*}{0.001} & 1.864 \\
\hline Herbivore/omnivore & Reservoir & 22 & 9.09 & 6.36 & 22.73 & 35.91 & 0 & 25.91 & & 3.846 \\
\hline Leporinus fasciatus (Bloch, 1794) & River & 4 & 50 & 25 & 0 & 0 & 0 & 25 & \multirow{2}{*}{1.000} & 2.667 \\
\hline Herbivore/omnivore & Reservoir & 4 & 35 & 40 & 0 & 15 & 0 & 10 & & 3.175 \\
\hline Leporinus friderici (Bloch, 1794) & River & 139 & 75.18 & 8.59 & 0 & 1.37 & 8.67 & 5.76 & \multirow{2}{*}{0.001} & 1.713 \\
\hline Herbivore/omnivore & Reservoir & 21 & 29.52 & 32.38 & 0 & 0.95 & 29.52 & 7.62 & & 3.508 \\
\hline Leporinus granti Eigenmann, 1912 & River & 14 & 60.71 & 21.43 & 0 & 0 & 7.14 & 10.71 & \multirow{2}{*}{0.040} & 2.320 \\
\hline Herbivore/omnivore & Reservoir & 4 & 0 & 0 & 0 & 20 & 65 & 15 & & 2.062 \\
\hline Moenkhausia chrysargyrea (Günther, 1864) & River & 4 & 50 & 50 & 0 & 0 & 0 & 0 & \multirow{2}{*}{0.657} & 2.000 \\
\hline Omnivore/omnivore & Reservoir & 4 & 0 & 50 & 0 & 10 & 20 & 20 & & 2.941 \\
\hline Moenkhausia georgiae Géry, 1966 & River & 32 & 46.56 & 47.6 & 0 & 1.46 & 0.63 & 3.75 & \multirow{2}{*}{0.001} & 2.247 \\
\hline Omnivore/omnivore & Reservoir & 5 & 0 & 20 & 0 & 60 & 0 & 20 & & 2.273 \\
\hline Myleus rhomboidalis (Cuvier, 1818) & River & 6 & 96.67 & 0 & 0 & 3.33 & 0 & 0 & \multirow{2}{*}{0.012} & 1.069 \\
\hline Herbivore/omnivore & Reservoir & 3 & 0 & 0 & 0 & 40 & 33.33 & 26.67 & & 2.922 \\
\hline Myleus ternetzi (Norman, 1929) & River & 145 & 97.4 & 1.45 & 0 & 0.19 & 0 & 0.97 & 0.248 & 1.054 \\
\hline Herbivore/herbivore & Reservoir & 8 & 95 & 5 & 0 & 0 & 0 & 0 & 年 & 1.105 \\
\hline Poptella brevispina Reis, 1989 & River & 112 & 35.25 & 60.8 & 0 & 0.89 & 1.60 & 1.46 & 0.00 & 2.022 \\
\hline Omnivore/invertivore & Reservoir & 48 & 3.13 & 63.33 & 0 & 27.71 & 0.42 & 5.42 & (1) & 2.075 \\
\hline Parauchenipterus galeatus (Linné, 1766) & River & 5 & 5 & 65 & 0 & 0 & 30 & 0 & 0.483 & 1.942 \\
\hline Omnivore/omnivore & Reservoir & 18 & 21.11 & 65.56 & 0 & 0 & 11.11 & 2.22 & & 2.053 \\
\hline Triportheus rotundatus (Schomburk, 1841) & River & 201 & 63.81 & 30.34 & 0 & 1.08 & 3.71 & 1.06 & 0.001 & 1.996 \\
\hline Omnivore/omnivore & Reservoir & 147 & 33.88 & 31.77 & 7.82 & 25.31 & 0 & 0.544 & & 3.498 \\
\hline Mean & River & & 30.41 & 28.06 & 0.14 & 2.30 & 15.12 & 23.21 & & \\
\hline & Reservoir & & 11.92 & 24.85 & 3.89 & 24.66 & 18.58 & 16.08 & & \\
\hline
\end{tabular}


Table 2. Results of the Analysis of similarity between the trophic structures of the Sinnamary River and the Petit-Saut Reservoir. Feeding guilds contributions to the dissimilarity. Biomass are expressed in grams captured by the 2 sets of nets $\left(1000 \mathrm{~m}^{2}\right)$.

\begin{tabular}{lrrrrrr}
\hline \multicolumn{1}{c}{ Guild } & \multicolumn{1}{c}{ RIVER } & \multicolumn{2}{c}{ RESERVOIR } & & & \\
& Av. biomass & \multicolumn{1}{c}{ Av. biomass } & Av. Diss & Diss/SD & Contrib\% & Cum.\% \\
\hline Piscivore & 22627.65 & 5591.10 & 17.61 & 1.36 & 28.27 & 28.27 \\
herbivore & 17267.13 & 898.22 & 13.89 & 1.41 & 22.29 & 50.56 \\
omnivore & 10332.35 & 15771.56 & 12.15 & 1.14 & 19.51 & 70.07 \\
détritivore & 8221.80 & 9130.89 & 11.39 & 0.75 & 18.29 & 88.36 \\
invertivore & 6250.59 & 7321.27 & 6.53 & 1.08 & 10.49 & 98.85 \\
Total & 65136.68 & 39097.31 & & & & \\
\hline
\end{tabular}

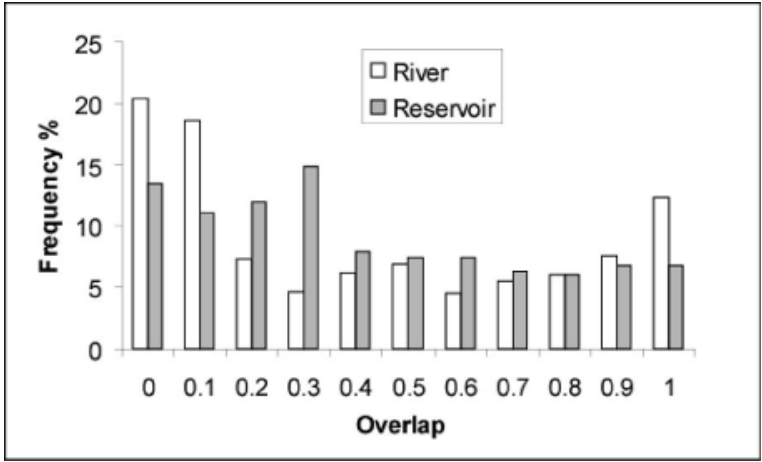

Fig. 3. Distribution of the frequency of overlaps values between species stomach contents in the Sinnamary River and the Petit-Saut Reservoir.

The weight contribution to the reservoir community of species having changed their diet in the reservoir was high. These species represented $59.28 \%$ of the total capture (Fig. 4).

\section{Discussion}

It is generally accepted that fish species are mainly opportunistic in their feeding habits (LoweMcConnell 1987, Araujo-Lima et al. 1995, Matthews 1998). This observation led many authors to consider the guild concept as highly relative (Gerking 1994). However in a study of a rich fish assemblage from the Amazon floodplain, Mérona \& Rankin-de Mérona (2004) showed that many species could be considered as feeding specialists. A specialist or stenophagous species cannot survive in an environment lacking the food resource it is adapted to. That means it is limited in its distri-

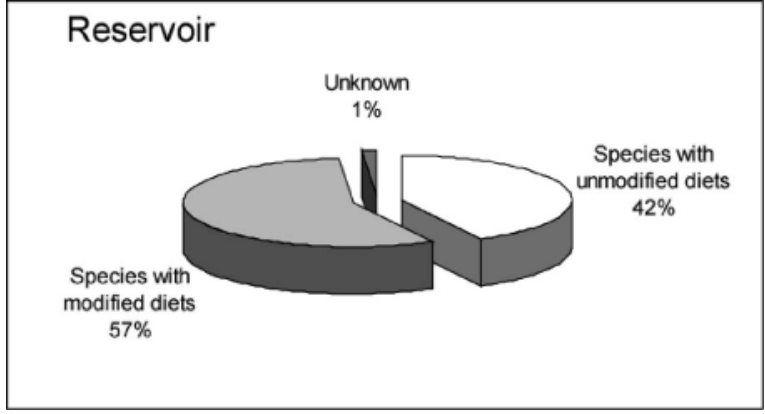

Fig. 4. Relative biomass contribution in the capture of fish species based on their ability to change their feeding habits in the PetitSaut Reservoir.

bution and will consume the same food in the different environments where it occurs. In this study we showed different responses from species pertaining to the same feeding guilds to the drastic changes in the environment induced by the formation of the reservoir. Some species radically changed the quality of their food while other did not. The changes affecting the diets of invertivores, piscivores and omnivores are not fundamental in the sense that they probably do not involve strong modification of their feeding behavior. Conversely some herbivores and detritivores seemed to deeply modify the way they feed. The availability of terrestrial plant material is much reduced in the reservoir but some herbivores maintained populations by preying upon fish. Leporinus friderici and Myleus rhomboidalis have been already known to show a propensity for omnivorous habits (Boujard et al. 1990, Albrecht \& Caramaschi 2003). Conversely, Myleus ter$n e t z i$ is strictly folivorous and eats exclusively allochtonous food (Boujard et al. 1990). Because of the diffi- 
culty to separate partially digested algal material from true detritus in the gut, we included in the detritivore guild two different kinds of species. Some, like Curimata cyprinoides and Cyphocharax sp. feed preferentially upon periphytic algae, other, like $H$. gymnorhynchus and $H$. unimaculatus are more mud eaters. In the reservoir the former species found their preferred food in large supply because of the presence of tree trunks on which attached algae develop. Conversely the access for fish to the sediment deposited on the bottom of the reservoir is limited by the anoxic character of the lake hypolimnion (Richard et al. 1997). Only the marginal areas, where there was a great development of chironomids and other benthic invertebrates (Horeau et al. 1997), are accessible to benthic fishes. This fact explains the presence of large amounts of aquatic invertebrates in the stomachs of $H$. gymnorhynchus and $H$. unimaculatus. Given the specialized morphology and the scraping behavior of the first species, it is likely that the ingestion of aquatic invertebrates is accidental and cannot be interpreted as a change in feeding behavior for this species. Conversely $H$. unimaculatus which has been often described as an opportunistic feeder picking selected items on the bottom (Ferreira 1984, Leite 1987, Mérona et al. 2001), probably actively search for invertebrates.

These modifications in individual species' diets led to changes in the position of these species in the feeding guilds. In the reservoir as compared with the river, we observed a large decrease of herbivores and piscivores and a parallel increase of the relative importance of omnivores and invertivores. Observations on large reservoirs in the tropics reveal a great development of piscivores (Ita 1984, Marshall 1984, SiawYang 1988, Hahn et al. 1998, Novoa et al. 1991,Mérona et al. 2001). According to Agostinho et al. (1999) this fact can be related to the presence in the river of piscivore species pre-adapted to lacustrine conditions, such as Cichla sp. and Plagioscion sp. (e.g., Tucurui reservoir: Petrere 1996, Mérona et al. 2001). In the Sinnamary River the high contribution of the piscivore guild is the consequence of the relative abundance of a large predator species: Hoplias aimara, a species which becomes rare in the reservoir where the piscivores are medium sized. As expected, herbivores, which in the Sinnamary River feed mainly upon the terrestrial marginal vegetation, diminished in abundance in the reservoir. Omnivores are generally dominant in relatively small reservoirs (Viera 1982, Ferreira 1984, Arcifa et al. 1988, Zarate et al. 1991, Agostinho et al. 1997, Hahn et al. 1997) but have not been reported to be abundant in Tucurui and Itaipu reservoirs. These observations support the hypothesis of a strong depen- dence of the fish community in reservoirs on the fish fauna in the river prior to impoundment. In very large rivers like the Tocantins River (Tucurui reservoir) and the Parana River (Itaipu reservoir) there are much more specialist species than in medium or small-sized rivers. According to Angermeier \& Karr (1983) the relation between diversity of feeding guilds and river size could be related to an increase of feeding niches along the upstream-downstream gradient. The increase of invertivores went with a switch from terrestrial to aquatic invertebrates, a fact which has also been shown in Itaipu Reservoir (Hahn et al. 1998). In the Petit-Saut Reservoir terrestrial invertebrates were still an abundant resource for fish because of the presence of great number of dead trees which house large termite's colonies. However aquatic invertebrates, as generally observed in reservoirs, develop rapidly in the littoral and pelagic zone and constitute the main resource available for invertivores.

Most of the studied species enlarged their food niche breadth in the newly formed lake, which means they diversified their diet. The consequence was a reduction in the number of specialist species as shown by a decrease of highest overlaps at the community level (those between members of the same specialist guild) and a parallel decrease of lowest overlaps (those between members of two different specialist guilds - Fig. 3). In order to coexist in the long-term, species must partition the resource in such a way as to avoid competition which could lead to the elimination of the less competitive species (Schoener 1974). However, as pointed out by Matthews (1998), high overlaps cannot be interpreted as indicating that competition is or is not occurring. Indeed, if the common resources are superabundant, at least in some periods of time, competition does not occur. An upsurge of production has been always observed in the first years of reservoir formation (Ackermann et al. 1973, Petr 1975, Bernacsek 1984) and can extend many years after the reservoir filling in situations where nutrients from the inundated land are abundant. This is obviously the case of Petit-Saut dam, situated in a forested area, and it is likely that, at the time of our observations, food resources were not limiting for fish. With the passage of time, the level of production in reservoirs eventually decreases and the food resource available to fish diminishes. In that situation biotic interactions between species outweigh the influence of abiotic conditions of the environmental filter in constraining fish community structure (Poff 1997). This observation emphasizes the importance of considering the state of a reservoir in analyzing the trophic structure of its fish community.

In the Petit-Saut Reservoir the phenomenon of diet 
plasticity appears to be extremely important in the formation of the trophic structure of the fish community as fish species changing their feeding habits represent more than half of the total biomass captured (Fig. 4). However this does not seem to be a general feature. In the Tucurui Reservoir the contribution of such species has been shown to be of marginal importance (Mérona et al. 2001). Again, the fact that Tucurui Dam was implanted on a very large river with many specialist feeders can explain this difference. Also, it must be pointed out that observations on Tucurui Reservoir were carried out in the very first years after impoundment when trophic organization of the fish community was still very unstable.

\section{Conclusion}

This work demonstrates the great impact of the plasticity of fish species diets on the trophic structuration of fish communities in the Petit-Saut Reservoir. Many species, even those which were considered as specialist feeders in the river, were able to change their diet in order to adapt to the new availability of food resources. The results suggest that, in the process of equilibration of a reservoir, a first selection of species is achieved through an environmental filter induced by the transformation of the river in a lake. This process may last a long time depending of the quantity of organic material decomposing after the filling. It is probably much longer in reservoirs situated in pristine forest where the vegetal biomass flooded is considerable.

Substantial losses to downstream fishery production as a result of dam construction have been reported from around the world (WCD, 2000). On another hand, productive reservoirs fisheries often follow from dam construction, although they are rarely anticipated (Kapetsky \& Petr 1984). As these authors have pointed out, planning must take place at the early pre-impoundment stages of reservoir development as one of the means for increasing benefits from African reservoir fisheries. The results presented here will contribute to forecast the type of species likely to develop in tropical reservoirs, as a function of the riverine fauna.

\section{Acknowledgements}

This study was partly funded by Electricité de France (EDF). The authors would like to thank the technical staff of HYDRECO, laboratoire de Petit-Saut and of IRD, centre de Cayenne, especially Michel Tarcy, Jean-Claude Bron, Roland Ruffine, Roland Aboikoni and Laurent Guillement.

\section{References}

Ackermann W.C., White G.F. \& Worthington E.B. (Eds.) 1973. Man-Made Lakes: Their Problems and Environmental Effects. American Geophysical Union, Washington, 847 p.
Agostinho A.A., Bini L.M. \& Gomes L.C. 1997. - Ecologia de communidades de peixes da área de influência do reservatório de Segredo. Pages 97-111 in Reservatório de Segredo. Bases ecológicas para o manejo. Agostinho A.A. \& Gomes L.C. (Eds.). Universidade Estadual de Maringá, Nupelia, Maringá, Paraná, Brazil.

Agostinho A.A., Julio Jr. H.F. \& Petrere Jr. M. 1994. - Itaipu reservoir (Brazil): impacts of the impoundment on the fish fauna and fisheries. Pages 171-184 in Rehabilitation of Freshwater fisheries. Cowx I. G. (ed). Blackwell Scientific Publications, Oxford.

Agostinho A.A., Miranda L.E., Bini L.M., Gomes L.C., Thomaz S.M. \& Suzuki H.I. - 1999. Patterns of Colonization in Neotropical Reservoirs, and Prognoses on Aging. Pages 227-265 in Theoretical Reservoir Ecology and its Applications. Tundisi J. G.\& Straskraba M. (eds). International Institute of Ecology, Brazilian Academy of Sciences and Backhuys publishers, São Carlos, Rio de Janeiro \& Leiden.

Albrecht M.P. \& Caramaschi E.P. 2003. - Feeding ecology of Leporinus friderici (Teleostei ; Anostomidae) in the upper Tocantins River, Central Brazil, before and after installation of a hydroelectric plant. Stud. Neotrop. Fauna Environ., 38, 33-40.

Angermeier P.L. \& Karr J.R. 1983. - Fish communities along environmental gradients in a system of tropical streams. Environ. Biol. Fishes., 9, 117-135

Araujo-Lima C.A.R.M., Agostinho A.A. \& Fabre N.N. 1995. - Trophic aspects of fish communities in Brazilian rivers and reservoirs. Pages 105-136 in Limnology in Brazil. Tundisi J. G., Bicudo C. E. M. \& Matsamura-Tundisi T. (eds). Brazilian Academy of Sciences/Brazilian Limnological Society, São Paulo.

Arcifa M.S., Froehlich O. \& Northcote T.G. 1988. - Distribution and feeding ecology of fishes in a tropical Brazilian reservoir. Mem. Soc. Ci. Nat. La Salle., 48 (Suppl.2), 301-326.

Bernacsek G. M. 1984. - Guidelines for dam design and operation to optimize fish production in impounded river basins. CIFA Tech. Pap., 11, 98 p.

Boujard T., Sabatier D., Rojas-Beltran R., Prevost M.F. \& Renno J.F. 1990. - The food habits of three allochtonous feeding characoids in French Guiana. Rev. Ecol., 45, 247-258.

Clarke K.R. 1993. - Non-parametric multivariate analysis of changes in community structure. Aust. J. Ecol., 18,117-143.

Densen W.L.T. van \& Morris M.J. (eds) 1999. - Fish and Fisheries of Lakes and Reservoirs in Southeast Asia and Africa. Westbury Academic \& Scientific Publishing, Westbury, UK.

Ferreira E.J.G. 1984. - A ictiofauna da represa hidrelétrica de CuruáUna, Santarem, Par. II - Alimentação e hábitos alimentares das principais especies. Amazoniana, 9, 1-16.

Gerking S.D. 1994. - Feeding ecology of fish. Academic Press, San Diego, CA.

Hahn N.S., Agostinho A.A., Gomes L.C. \& Bini L.M. 1998. - Estrutura trófica da ictiofauna do reservatório de Itaipu (Parana-Brasil) nos primeiros anos de sua formação. Interciencia, 23, 299-305.

Hahn N.S., Fugi R., Almeida V.L.L. de, Russo M.R. \& Loureiro V.E. 1997. - Dieta e atividade alimentar de peixes do reservatório de Segredo. Pages 141-162 in Reservatório de Segredo. Bases ecológicas para o manejo. Agostinho A.A. \& Gomes L.C. (Eds.).Editora da Universidade Estadual de Maringá., Maringá, Paraná, Brazil.

Hamley J.M. 1975. - Review of gillnet selectivity. J. Fish. Res. Board Can., 32, 1943-1969.

Horeau V., Cerdan P. \& Champeau A. 1997. La mise en eau du barrage hydroélectrique de Petit-Saut (Guyane): ses conséquences sur les peuplements d'invertébrés aquatiques et sur la nourriture des poissons. Hydroécol. Appl., 9, 213-240.

Hughes R.N. 1993. - Introduction. Pages 1-9 in Diet Selection. Hughes R.N. (ed). Blackwell Scientific Publications, Oxford.

Ita E.O. 1984. Kainji (Nigeria). Pages 43-104 in Status of African re- 
servoir fisheries / Etat des pêcheries dans les réservoirs d'Afrique. Kapetsky J.M. \& Petr T. (Eds.),. FAO, Rome. CIFA Tech. Pap. 10.

Kapetsky J.M. \& Petr T. (eds.) 1984. - Status of African reservoir fisheries. FAO, Rome. CIFA Tech. Pap., 10, 326 p.

Keith P., Le Bail P.Y. \& Planquette P. 2000. - Atlas des Poissons de Guyane. tome 2, fasc. I, Patrimoines naturels, MNHN/SPN, 43, 286 p.

Kubečka J. 1993. - Succession of fish communities in reservoirs of Central and Eastern Europe. Pages 153-168 in Comparative reservoir limnology and water quality management. Straškraba M., Tundisi J. G. \& Duncan A. (eds). Kluwer Academic Publishers, the Netherlands.

Le Bail P.Y., Keith P. \& Planquette P. 2000. Atlas des Poissons de Guyane. tome 2, fasc. II, MNHN/SPN, 43(II), 307 p.

Leite R.G. 1987. - Alimentação e hábitos alimentares dos peixes do Rio Uatumã na área de abrangência da usina hidrelétrica - Balbina. Amazonas, Brasil. Diss. Mestrado, INPA/FUA, Manaus-Am, Brazil, 92 p.

Lowe McConnell R.H. 1987. - Ecological studies in tropical fish communities. Cambridge University Press. Cambridge, 382 p.

Marshall B.E. 1984. - Kariba (Zimbabwe/Zambia). Pages 105-154 in Status of African reservoir fisheries / Etat des pêcheries dans les reservoirs d'Afrique. Kapetsky J. M. \& Petr T. (Eds.). FAO, Rome. CIFA Tech. Pap. 10.

Matthews, W.J. 1998. - Patterns in freshwater fish ecology. Chapman \& Hall, New York, 756 p.

Mérona B. de 1990. - Amazon fisheries : general characteristics based on two case-studies. Interciencia, 15, 461-468

Mérona B. de \& Rankin-de Mérona J. 2004. - Food resource partioning in a fish community of the central Amazon floodplain. Neotrop. Ichthyol., 2, 45-54

Mérona B. de, Santos G. M. dos \& Almeida R. G. de. 2001. - Short term effects of Tucurui Dam (Amazonia, Brazil) on the trophic organization of fish communities. Environ. Biol. Fishes, 60, 375392.

Mérona B. de, Vigouroux R. \& Horeau V. 2003. - Changes in the food resources and their utilization by fish assemblages in a large tropical reservoir in South America (Petit-Saut dam, French Guiana). Acta Oecol., 24, 147-156

Morisita M. 1959. - Measuring interspecific association and similarity between communities. Mem. Fac. Sci. Kyushu Univers. Ser. E (Biol.), 3, 65-80.

Novoa D., Koonce J., Ramos F. \& Locci A. 1991. - Evaluacion del potencial pesquero del lago de Guri (Venezuela). Estrategias de ordenamiento pesquero. Pages 112-146 in Segundo Taller Internacional sobre Ecologia y Manejo de Peces en Lagos y Embalses. Vila I. (ed.) FAO, Oficina Regional para America Latina y el Caribe, COPESCAL Documento Tecnico.

Petr T. 1975. - On some factors associated with the initial high fish catches in new African man-made lakes. Arch. Hydrobiol., 75, 3942.

Petrere Jr. M. 1996. - Fisheries in large tropical reservoirs in South America. Lakes Reservoirs: Res. Manage., 2, 111-133.

Pianka E.R. 1973. - The structure of lizard communities. Ann. Rev. Ecol. Syst., 4, 53-74.

Planquette P., Keith P. \& Le Bail P.Y. 1996. - Atlas des poisson d'eau douce de Guyane. tome 1, Collection du Patrimoine Natu- rel, vol 22, IEBG-MNHN, INRA,Min. Env. Paris, 429 p.

Poff N.L. 1997. - Landscape filters and species traits: towards mechanistic understanding and prediction in stream ecology. J.N Am. Benthol. Soc., 16, 391-409.

Richard S., Arnoux A. \& Cerdan P. 1997. - Evolution de la qualité physico-chimique des eaux de la retenue et du tronçon aval depuis le début de la mise en eau du barrage de Petit-Saut. Hydroécol. Appl., 9, 57-8.

Santos G.M. dos \& Mérona B. de 1996. - Impactos imediatos da UHE Tucurui sobre as communidades de peixes e a pesca. Pages 251-258 in Energia na Amazônia. Magalhaes S.B., Britto R. de C. \& Castro E.R. de (eds). Museu Paraense Emilio Goeldi, UFPA, Assoc. Univ. Amazônicos, Belem, PA, Brazil.

Schoener T.W. 1974. - Resource partioning in ecological communities. Science, 185, 27-39

Shrimpton R. \& Giubliano R. 1979. - Consumo de alimentos e alguns nutrientes em Manaus, Amazonas. Acta Amazonica, 9, $117-$ 141.

Siaw-Yang Y. 1988. - Food resource utilization partitioning of fifteen fish species at Bukit Merah Reservoir, Malaysia. Hydrobiologia, 157, 143-160.

Tejerina-Garro F.L. \& Mérona B. de 2000. - Gill net sampling standardisation in large rivers of French Guiana (South America). Bull. Fr. Pêche Piscic., 357/358, 227-240.

Tejerina-Garro F.L., Fortin R. \& Rodriguez M.A. 1998. - Fish community structure in relation to environmental variation in floodplain lakes of the Araguaia River, Amazon Basin. Environ. Biol. Fishes, 51, 399-410.

Tito de Morais L. \& Lauzanne L. 1994. - Zonation longitudinale des peuplements ichtyques avant mise en eau de la retenue de PetitSaut (Guyane française). Rev. Hydrobiol. Trop., 27, 467-483.

Tonn W.M., Magnuson J.J., Rask M. \& Toivonen J. 1990. - Intercontinental comparison of small-lake fish assemblages: the balance between local and regional processes. Am. Nat., 136, 345375.

Viera I. 1982. - Aspectos sinecológicos da ictiofauna de Curuá-Una, represa hidroelétrica da Amazônia brasileira. Diss. Mestrado, Universidade Federal de Juiz de Fora, Brazil, 107 p.

WCD (World Commission of Dams). 2000. - Dams and Development. A new framework for decision-making. Earthscan Pub. Ltd. London, UK, 356 p.

Welcomme R.L. 1979. - Fisheries Ecology of Floodplain Rivers. Longman, London and New-York, 317 p.

Welcomme R.L. \& Mérona B. de. 1988. - Fish communities of rivers. Pages 251-276 in Biology and Ecology of African Freshwater fishes. Levêque C., Bruton M.N. \& Ssentongo G.W. (eds) ORSTOM, Paris.

Wootton R.J. 1999. - Ecology of Teleost Fishes. Kluwer Academic Publishers, Dordrecht, The Netherlands, 386 p.

Zarate M.V., Martinez J.R. \& Sanchez F.R. 1991. - Evaluacion de las pesquerias del embalse de el Guajaro, Colombia. Pages 184-196 in Segundo Taller Internacional sobre Ecologia y Manejo de Peces en Lagos y Embalses. Vila I. (Ed.), FAO, Oficina Regional para America Latina y el Caribe, COPESCAL, Documento Tecnico.

Zaret T. M. \& Rand A.S. 1971. - Competition in tropical stream fishes: support for the competitive exclusion principle. Ecology, 52, 336-342. 